\title{
Standardization of farm mechanization practices for the benefit of farmers
}

\section{CHOWDA REDDY AND B.K. NARAYANA SWAMY}

Received : 14.07.2017; Revised : 20.08.2017; Accepted : 05.09.2017

See end of the Paper for authors' affiliation Correspondence to :

\section{CHOWDA REDDY}

Department of Farm Power and Machinery, Rai

Technology University, BENGALURU (KARNATAKA) INDIA

Email : chowdas705@gmail. com
- ABSTRACT : In post-independence era, Indian farming has been transformed from subsistence farming to modern agriculture. The sources of energy on farm power, agricultural practices and farm technologies and crops have been under gone a sea change. This is the evident from the data on number of mechanical power units used in farming. Number of tractors, electric motors, diesel engines, power tillers and self-propelled combine harvesters has increased by manifolds during the second half the twentieth century. The progress of farm mechanization has been closely linked with the overall improvement in agriculture production and productivity. The results has been shown in standardization of farm mechanization in ragi and maize crop the relevancy weightage considered was more than 0.70 values, Relevancy percentage was consider was more than $70 \%$ of values, Mean relevancy score was more than 2.0 values. Reliability values found in ragi and maize crop is follows, split-half method $\left(\mathrm{r}_{1 / 2}\right) 0.9132,0.9138$ and whole test method (RII) $0.9546,0.9550$ and validity values found $0.9770,0.9772$, respectively. The research study is prominent agricultural engineering extension technology to develop dry land agriculture and enhance the productivity and production of dry land farmers in Karnataka. It is the research which will be more helpful to farmers to promote old farm mechanization practices to advanced farm mechanization practices in agriculture.

- KEY WORDS : Bengaluru rural, Maize, Mechanization, Ragi, Standardization, Reliability, Validity

- HOW TO CITE THIS PAPER : Reddy, M. Chowda and Swamy, B.K. Narayana (2017). Standardization of farm mechanization practices for the benefit of farmers. Internat. J. Agric. Engg., 10(2) : 481-487, DOI: 10.15740/HAS/IJAE/10.2/481-487. 